\title{
LANDSCAPE-ECOLOGICAL OPTIMIZATION OF HYDRIC POTENTIAL IN FOOTHILLS REGION WITH DISPERSED SETTLEMENTS - A CASE STUDY OF NOVÁ BOŠÁCA, SLOVAKIA
}

\author{
PETROVIČ, F. ${ }^{1 *}$-STRÁNOVSKÝ, P. ${ }^{1}$ - MUCHOVÁ, Z. ${ }^{2}$ - FALŤAN, V. ${ }^{3}-$ SKOKANOVÁ, H. ${ }^{4}$ \\ HAVLÍČEK, M. ${ }^{4}-$ GÁBOR, M. ${ }^{3}-$ ŠPULEROVÁ, J. ${ }^{5}$ \\ ${ }^{I}$ Department of Ecology and Environmental Sciences, Faculty of Natural Sciences, Constantine \\ the Philosopher University in Nitra, Tr. A. Hlinku 1, 949 74, Nitra, Slovak Republic \\ ${ }^{2}$ Department of Landscape Planning and Land Consolidation, Horticulture and Landscape \\ Engineering Faculty, Slovak University of Agriculture in Nitra, Tr. A. Hlinku 2, 94976 Nitra, \\ Slovak Republic \\ ${ }^{3}$ Department of Physical Geography and Geoecology, Faculty of Natural Sciences, Comenius \\ University in Bratislava, Mlynská dolina, 84215 Bratislava 4, Slovak Republic \\ ${ }^{4}$ Department of Forest Ecology, Silva Tarouca Research Institute for Landscape and \\ Ornamental Gardening, Lidická 25/27, Brno, Czech Republic \\ ${ }^{5}$ Institute of Landscape Ecology, Slovak Academy of Sciences, Štefánikova 3, Bratislava, \\ Slovak Republic \\ *Corresponding author \\ e-mail:fpetrovic@ukf.sk
}

(Received $1^{\text {st }}$ Mar 2016; accepted $1^{\text {st }}$ Dec 2016)

\begin{abstract}
The article shows how to implement scientific results from a methodology of landscape ecological planning (LANDEP) into integrated river basin management. This methodology creates a framework of integrating research of land use structure with modelling hydric potential by using runoff curve number into the assessment and subsequent optimization of hydric potential in a foothills region of the Biele Karpaty Mts. Analysis and hydric evaluation of the study area shows that foothills region has a relatively high hydric potential. The research question is: could landscape ecological optimization reduce runoff significantly and improve hydric regime in the landscape. The proposed measures are linked to existing land use structure, where they increase the quality of existing hydric elements. They have character of non-technical solutions with maximum exploitation of the potential of ecosystem services, therefore they are economically undemanding. On the basis of our results, the proposed changes in land use will lead to the capture of water in landscape and an overall better use of water in landscape.
\end{abstract}

Keywords: land use structure, CN curves, retention, river basin management, Biele Karpaty Mts.

\section{Introduction}

In recent years, there is a higher frequency of torrential rains and related flash floods which is often thought as a result or an attribute of climate change. With the appearance of extreme flood situations a new space for research work has been created. Nevertheless, researchers should also study land use changes (Kozma et al., 2014) which can contribute to the occurrence and severity of these extreme weather events. Due to complexity, fast, dynamic and non-linear development, torrential rains belong to the challenging phenomena for the accurate weather forecasting. If we take into considerations a location of their occurrence and quantification of expressions, accurate 
forecasting is currently not possible for a period exceeding several tens of minutes. Consequences of these torrential rains are expressed by flash floods and subsequent soil erosion. These two types of events belong among the most dangerous weather events for human society in Central Europe, where their devastating effects are often reflected.

The most vulnerable regions are foothills of the Carpathians Mountains, where dominant land use is agriculture. Strengthening ecological stability of these foothills is important (Pavličková et al., 2004), as flash floods can cause damage especially in small basins with inappropriate spatial structure of land use. Land uses different from the primary landscape structure lead to disruption of functional ecosystems. This is reflected in changes not only in structure of landscapes, but also in their functions. Therefore a detailed knowledge of the structure and functioning of ecosystems is necessary (Kozová and Pauditšová, 2001).

The environment, local and global climate are affected by the ecosystems through the climate-ecosystem feedbacks (Drégelyi-Kiss et al., 2008). Correspondingly, structures, functions and services of ecosystems may be influenced by climate change. On local, regional and global scales, the most significant human impacts on the hydrologic system are caused by land-use change (Bhaduri et al., 2000; Izakovičová, 2000; Liekovský, Bezák, Izakovičová, 2010). Landscape structures as integral part of ecosystems integrated within landscape ecology was the subject of several authors (e.g. Naveh and Liebermann, 1990; Forman and Godron, 1993; Bastian, 2001; Estrada-Carmona et al. 2014; Muchová et al. 2016).

Scientific team led by Ružička and Miklós (1982) developed a detailed methodology of landscape-ecological planning (LANDEP), which is efficient in the process of territorial planning. A goal oriented application of the traditional landscape-ecological theory and methodology brings a new process for landscape management (Miklós, 1996; Hrnčiarová, 2003, Miklós and Špinarová, 2011). LANDEP represents an approach to the management of natural resources in different landscape ecological units by integrating environmental, economic and social issues. It is focused on sustainable benefits for future generations, while protecting natural resources, especially water, and minimizing negative environmental, economic and social impacts (Walmsley, 2002). As such it can be considered as a predecessor of ecosystem assessment focusing on ecosystem services (see e.g. Haines-Young and Potschin, 2008).

In case of river basins results from LANDEP can be applied in integrated river basin management. This term was used for the first time in proposal for management plan of Atchafalaya River basin in North America (Van Beek, 1981). It is a holistic approach and can be defined as a process of coordinating conservation, management and development of water, land and related resources across sectors within a given river basin, in order to maximise the economic and social benefits derived from water resources in an equitable manner while preserving and, where necessary, restoring freshwater ecosystems (GWP, 2000).

An essential step for dealing with integrated river basin management is adoption of Directive 2000/60/EC. Its purpose is to establish integrated framework of water for the EU policy, in order to protect physical and biological integrity of water systems and to reduce negative pressure on drinking water sources (Directive 2000/60/EC, 2000).

So far, application part of integrated river basin management and flood protection measures has been significantly behind scientific progress. As a crucial step we perceive application and integration of scientific research into the actual land use planning in the form of its implementation into Forest management plans, Water management plans and 
completed Territorial systems of ecological stability and Land consolidations. Quality of landscape documentation has great importance for their successful implementation.

One of the scientific methods that are used in integrated river basin management are modelling runoff with the help of runoff curve number. Methodology of runoff curve number (so called $\mathrm{CN}$ curves), using an empirical parameter for predicting direct runoff or infiltration from rainfall excess, was developed by the United States Department of Agriculture Natural Resources Conservation Service and is still popular and effective tool for runoff modelling (USDA, 1986; Ward and Trimble, 2004). An important part of the model is detail information about the spatial structure of landscape - the current land use. In the post-socialist countries there were significant changes in spatial structure of landscape due to several stages of transformation processes, which affected runoff, especially in areas with a dominant agricultural use. Changes were taking place also in foothills regions with typical historical structures, which are nowadays in many areas disappearing and are considered very vulnerable.

Our research is based on the LANDEP methodology by using methodology of CN curves and large-scale data processing for flood risks in a local area.

The aim of the paper is the proposal of possibility to harmonize the use of methodology LANDEP and integrated landscape management methodology for landscape ecological optimization of hydric potential of landscape in source and headwater areas. The method was applied in rural landscape with the historical dispersed settlement on the example of upper part of Bošáčka basin in the central part of the Biele Karpaty Mts.

\section{Materials and Methods}

\section{Study area}

Study area (Fig. 1) is situated in the Slovak Republic, Trenčín region, Nové Mesto nad Váhom district. Majority of the area is located in cadastre of Nová Bošáca and partly in cadastre of Zemianske Podhradie. It borders with Czech Republic in the north, where part of study area of micro-basin is situated. Due to the subject of research, the study area is determined based on micro-basins and consists of three units.

Landscape of the Biele Karpaty Mts. and Bošácka valley is characterized by a rich diversity of meadow and pasture habitats, supplemented with orchards and hedgerows, which is result of dispersed rural settlements and landscape management.

Detailed characteristics of the study area are part of the result section, namely chapter Landscape ecological analysis.

\section{Data}

Outputs from landscape-ecological optimization of potential hydric potential (i.e. fourth step in LANDEP) are an essential input into integrated management of basin. Within the evaluation of landscape-ecological significance in the assessment of integrated river basin management, emphasis is placed on positive functioning of ecological processes in the landscape, and natural resources management, especially water. It is necessary that soil receives as much rainwater as possible. Therefore significant environmental characteristics enter the evaluation process. These are in particular: 


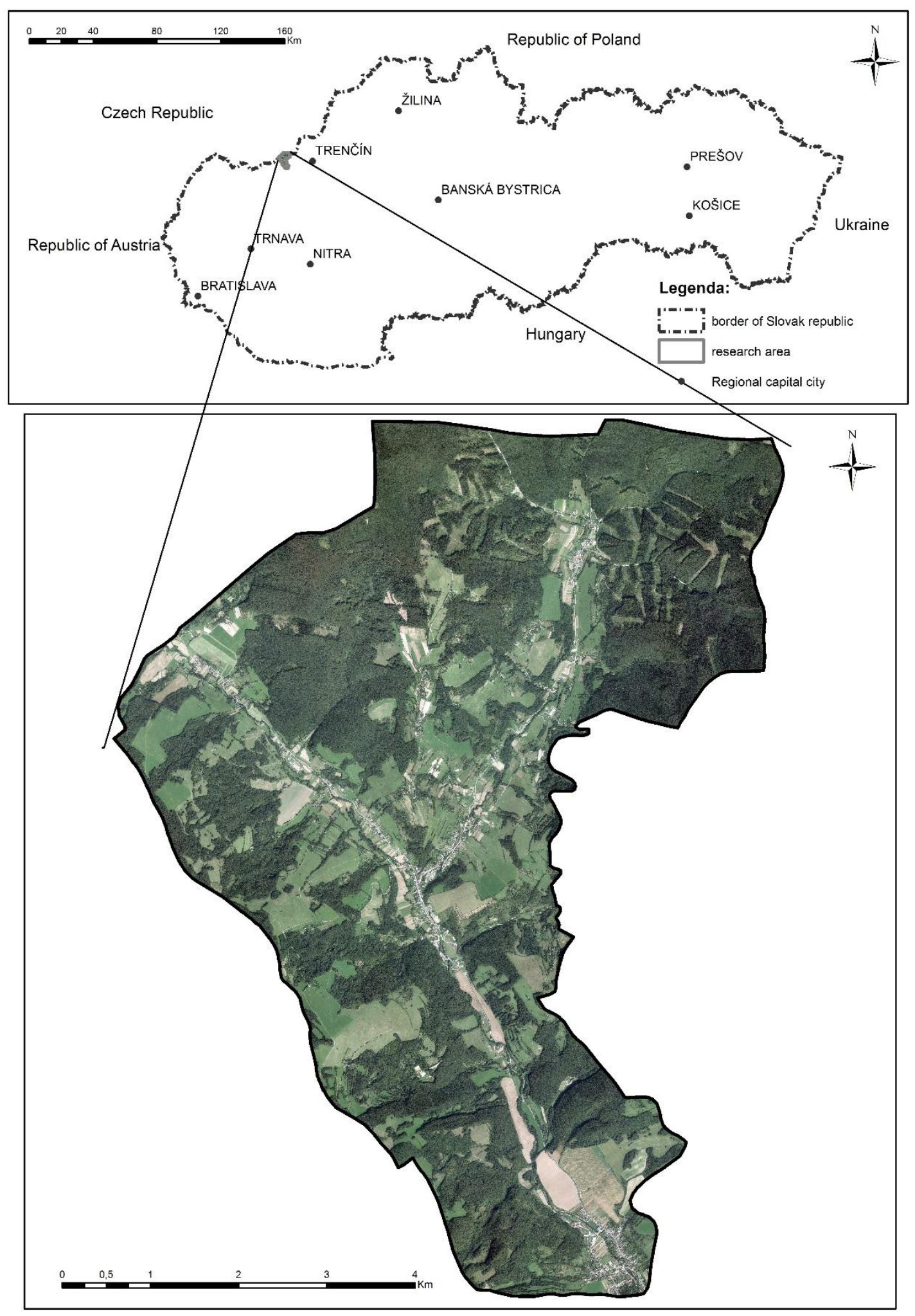

Figure 1. Location of study area 
- Hydrogeological characteristics of the basin (flow rate trough bedrocks)

- Meteorological conditions (average annual precipitation, significant precipitation events)

- Geomorphological characteristics of the basin (slope)

- Characteristics of soil (soil type, hydrologic soil group)

- Characteristics of forests (forest area, water balance, proportion of forest area with good water management of vegetation, etc.)

- Land use

- Interests of nature conservation and natural resources protection which are included in the legislation of landscape protection or other significant conventions (ecological priority of landscape)

Data from geological, pedological and geomorphological maps, The Slovak Hydrometeorological Institute, The National Forest Centre and Projects of Ecological Network were inputs for landscape-ecological analyses of the study area, which were verified and supplemented in field research. Terrain mapping of current landscape structure were according to universal legend of landscape elements was also part of analyses (Petrovič et al., 2009). It was adjusted to the aim of the research and to create current landscape structure map. Analyses were focused on selected landscape features which enter evaluation of potential retention and infiltration of study area.

Based on data from evaluated soil-ecological units and forest database, hydrologic soil groups (HSG) have been identified in the study area as a synthesis of hydric characteristics of sedimentary rocks and soil types, which are basis for $\mathrm{CN}$ curves methodology. Hydrologic soil groups for $\mathrm{CN}$ curves were determined according to the table of Hydrological categorization of soils (Table 1) (Antal and Igaz, 2006).

Table 1. Hydrologic soil groups (HSG) for CN method (modifed by Antal and Igaz., 2006; Janeček et al., 2002)

\begin{tabular}{|l|l|l|c|c|}
\hline HSG & $\begin{array}{l}\text { Infiltration and drainage soil } \\
\text { properties }\end{array}$ & \multicolumn{1}{|c|}{ Typical soil types } & $\begin{array}{c}\text { Representation of } \\
\text { grains of } \\
\text { I. category } \\
(\mathbf{\%} \text { hm. })\end{array}$ & $\begin{array}{c}\text { Consistent } \\
\text { infiltration } \\
\text { intensity } \\
\left(\mathbf{m m} . \mathbf{m i n}^{-1}\right)\end{array}$ \\
\hline A & $\begin{array}{l}\text { Soils with high infiltration } \\
\text { ability even when fully } \\
\text { saturated with water }\end{array}$ & $\begin{array}{l}\text { Deep sands and } \\
\text { gravel }\end{array}$ & $\begin{array}{c}\text { High speed } \\
>0,12\end{array}$ \\
\hline B & $\begin{array}{l}\text { Soils with medium infiltration } \\
\text { ability, even in the their fully } \\
\text { saturated with water and good } \\
\text { drainage }\end{array}$ & $\begin{array}{l}\text { Medium deep to } \\
\text { deep sand and silt- } \\
\text { sand soils }\end{array}$ & $10-45$ & $\begin{array}{c}\text { Medium speed } \\
0,06-0,12\end{array}$ \\
\hline C & $\begin{array}{l}\text { Soils with low infiltration } \\
\text { ability as well as in their fully } \\
\text { saturated with low drainage }\end{array}$ & $\begin{array}{l}\text { Clay-silt till clay } \\
\text { shallow soil }\end{array}$ & $45-75$ & $\begin{array}{c}\text { Low speed } \\
0,02-0,06\end{array}$ \\
\hline D & $\begin{array}{l}\text { Soils with very low infiltration } \\
\text { capacity and without drainage }\end{array}$ & $\begin{array}{l}\text { Clay or soils with } \\
\text { limited drainage and } \\
\text { infiltration ability }\end{array}$ & $>75$ & $\begin{array}{c}\text { Very low speed } \\
<0,02\end{array}$ \\
\hline
\end{tabular}

\section{Methods}

Theory and methods of LANDEP distinguishes two basic parts. The scientific content is included in the first part of the system as landscape-ecological analysis of a 
studied area. The second part includes landscape-ecological optimization of land use, which synthesises data and results from the first part.

The aim of the landscape-ecological synthesis in LANDEP is to create useable complex set of information about landscape characteristic for each landscape unit of a study area. In particular, LANDEP distinguishes four steps: the first step is represented by landscape ecological analysis that gives detailed information about all components of a study area. This is followed by landscape ecological synthesis which results in establishment of landscape ecological complexes; in case of integrated river management these complexes would be represented by units with different hydric potential. Third step, so called evaluation, confronts landscape features that are reflected in landscape ecological complexes with society requirements for the development of an area. The final step, proposition, proposes optimal localization of socio-economic activities in the landscape. The aim of this step is to harmonize its current environmental performance of the landscape with the proposed use.

In our case, the proposition aims at creating ecologically optimal landscape structure where the proposed use, including alternatives, is most suitable for every type of landscape ecological complexes. Proposition of optimal landscape structure is based on the potential possibilities of landscape structure and requirements of its current state.

Methodology of integrated river basin management (IMP) (Lepeška, 2005, 2013) was used to specify attributes entering evaluation of hydric potential of the landscape. The methodology is partly derived from methodology of evaluation of landscape carrying capacity (LCC) (Hrnčiarová et. al., 1997), which is based on basic procedures of LANDEP (Ružička and Miklós, 1982). A CN curve was used in the synthesis method. It was introduced on the basis of many annual observations of drainage on agricultural land. Therefore, the input characteristics for calculating the surface runoff according to $\mathrm{CN}$ method characterize in detail not only hydrological conditions but also land use. The value of $\mathrm{CN}$ is between 0 and 100. A value 100 means that all rainwater that falls on the catchment area or entire river basin flows away as surface runoff. In case that $\mathrm{CN}$ value is 0 all rainwater is infiltrated. $\mathrm{CN}$ value is synthesis of: Hydrologic soil group, Current landscape structure, Hydrologic characteristic of the various soil cultivation methods and Hydrologic characteristic of soil moisture (index determination of previous rainfall). $\mathrm{CN}$ values are included into the calculation of potential retention $\mathrm{A}$ $(\mathrm{mm})$, which is the basis for the calculation of direct runoff $\mathrm{H}_{0}(\mathrm{~mm})$ and runoff volume $\mathrm{O}\left(\mathrm{mm}^{3}\right)$ (Gajdošík et al., 2005). Following calculation of potential retention was used (Gajdošík et al., 2005):

$$
A=25,4 *(1000 / C N-10)
$$

Where $\mathrm{A}$ - potential retention $(\mathrm{mm})$

Based on previous data (runoff $\mathrm{CN}$ curve numbers and potential retention $\mathrm{A}$ ) with the addition of the proposed precipitation volume (in the calculations, we use the sum of torrential rains 06/07/1997 - $120.02 \mathrm{~mm}$ ) amount of direct runoff $\mathrm{H}_{\mathrm{o}}(\mathrm{mm})$ was calculated. Subsequently, from $\mathrm{H}_{\mathrm{o}}$ values the amount of surface runoff at the level of unit was calculated (pixel $5 \mathrm{~m}$ x $5 \mathrm{~m}$ ) $-\mathrm{O}_{\text {bunka }}\left(\mathrm{m}^{3}\right)$, which using Arc Hydro - Flow accumulation toll entering into the calculation of the surface runoff volume in the river basin $\mathrm{O}_{\mathrm{O}, \mathrm{P}}\left(\mathrm{m}^{3}\right)$.

The total volume of basin surface runoff $\mathrm{O}_{\mathrm{op}}\left(\mathrm{m}^{3}\right)$ was calculated through the function Flow Accumulation. This function as input requires a calculated function Flow 
Direction, which we obtained from hydrologically correct digital elevation model (DMR), thereby relief shape (topography) entered the calculation.

Runoff curves method is based on the assumption that the ratio of the runoff volume to total torrential rain is equal to the ratio of the water volume collected during runoff to the potential volume that can be collected. Runoff does not start immediately, but after some initial loss, which is the sum of interception, infiltration and surface accumulation, which was estimated based on experimental measurements at $20 \%$ of the potential retention $\left(I_{a}=0,2\right.$ A). The equation to determine the amount of direct runoff:

$$
H o=(H s-0.2 A) 2 /(H s+0,8)
$$

$$
\mathrm{Ho}=(\mathrm{Hs}-0.2 \mathrm{~A})^{2} /(\mathrm{Hs}+0.8 \mathrm{~A})
$$

Where $\mathrm{Hs} \geq 0,2 \mathrm{~A}$

$\mathrm{H}_{\mathrm{o}}$ - amount of direct runoff [mm]

$\mathrm{H}_{\mathrm{s}}$ - total proposed precipitation [mm]

A - potential retention $[\mathrm{mm}]$

For proposing measures of landscape-ecological optimization we partly used catalogue of non-technical flood control measures which was implemented into the GIS environment during the modelling process by using modelling tool Arc Hydro. This procedure was implemented by Rozsívalová (2007) in her work for the Ministry of the Environment of the Czech Republic. By applying proposed measures of landscapeecological optimization into modelling tool Arc Hydro, we were able to receive final calculation of the optimized surface runoff volume in the study area.

\section{Results}

\section{Landscape ecological analysis}

Study area is geologically part of the Western Carpathians, which are part of Central European Alpide. From geological point of view they are mostly covered with sedimentary rocks. South-western part is covered with flysch where claystone is dominant, the northern and north-western part is mostly covered with sandstone with a dominance of flysch and central part is mostly covered by flysch. Regular appearance of slope deformation is typical for this area. Relief of the Biele Karpaty Mts. largely reflects the different resilience of various flysch layers to weathering. Geomorphologic factors, mostly slope, significantly affect runoff conditions and ability of landscape to infiltrate rainfall (Fig. 2).

Atmospheric precipitation is crucial resource of the water in the area. In the lower part of the territory there is $330-430 \mathrm{~mm}$ of precipitation during vegetation period and $250-300 \mathrm{~mm}$ of precipitation during the winter. In the highest part of the territory there is $500-600 \mathrm{~mm}$ of precipitation during vegetation period and $350-400 \mathrm{~mm}$ of precipitation during the winter. The area is susceptible to flash floods; Kravarčík et al. (2000) recorded the most devastating floods in the cadastral area of Nová Bošáca which were results after short intensive rainfall, in April 1994 and 1999, in July 1972 and 1997 and in August 1972. 
Study area is situated in Váh River basin. Ridge of Váh River and Morava River basins mostly follows the main ridge of the Biele Karpaty Mts.. Considerable flow volatility is typical for the streams of the Biele Karpaty Mts., which is caused particularly due to small retention capacity of the flysch zone with the terrain morphology and climate factors. Altitude, slope conditions and characteristic of the substrate cause rapid rainwater runoff. Therefore only small amount of groundwater resources are accumulated. Besides natural factors insensitive ways of landscape management are also reflected, such as extensive deforestation, removing of natural boundaries, changes in natural structure of forest, transformation of grasslands into arable land even on high slopes, growing unsuitable crops, using heavy machinery, stream regulation, melioration and other factors.

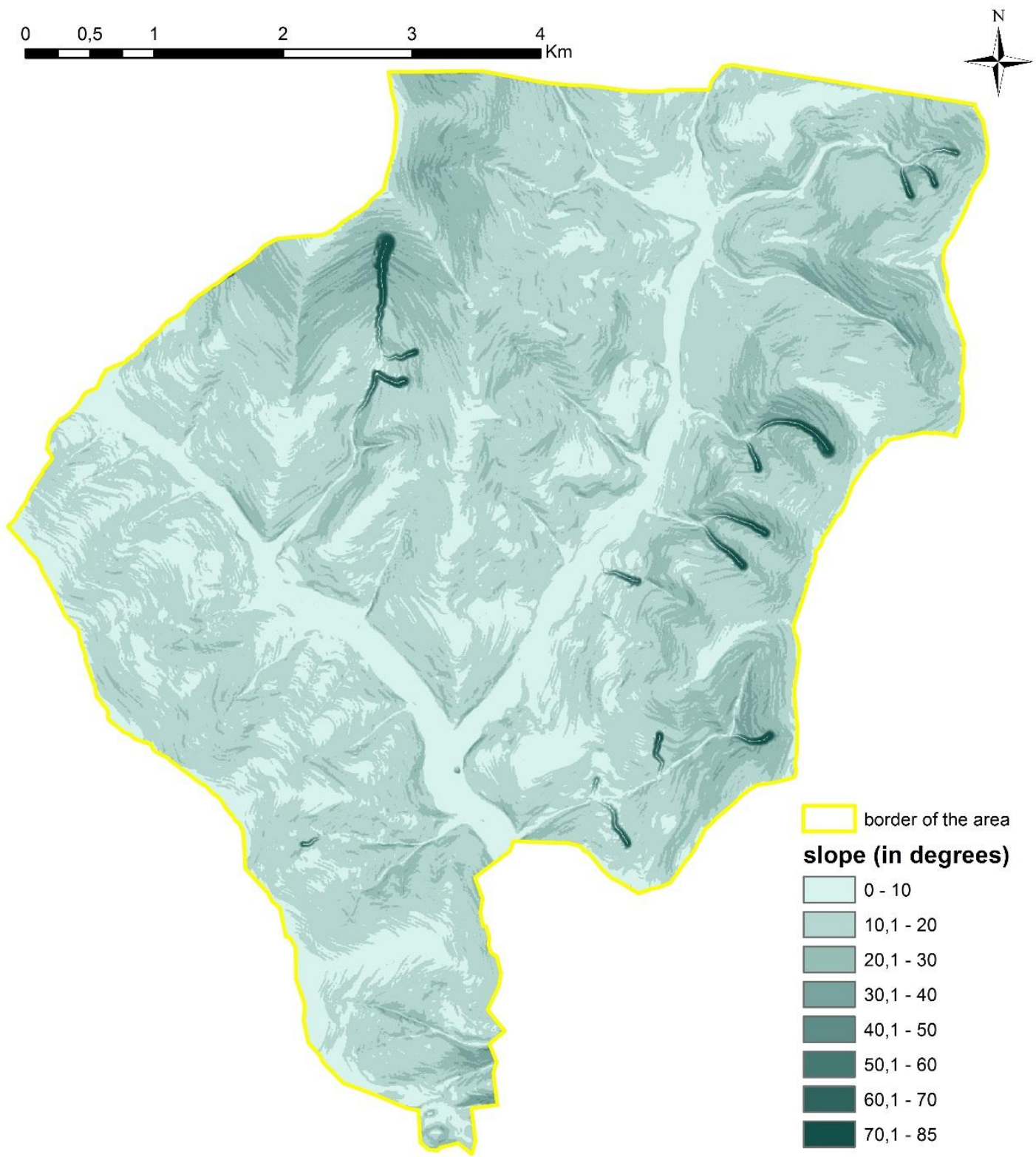

Figure 2. Slope map of study area 
Predominant soil type of the Biele Karpaty Mts. is represented by less fertile 'brown soils' (cambisols), whose fertility mainly depends on the substrate and the water regime. On the hilly parts of Biele Karpaty Mts. ridge, oligotrophic cambisols on acid substrates are typical. River valleys are covered by alluvial soils (VÚPOP, 2013). Based on data from evaluated soil-ecological units and forest database, four hydrologic soil groups (HSG) have been identified (Table 1) with only three being present in the study area (Fig. 3).

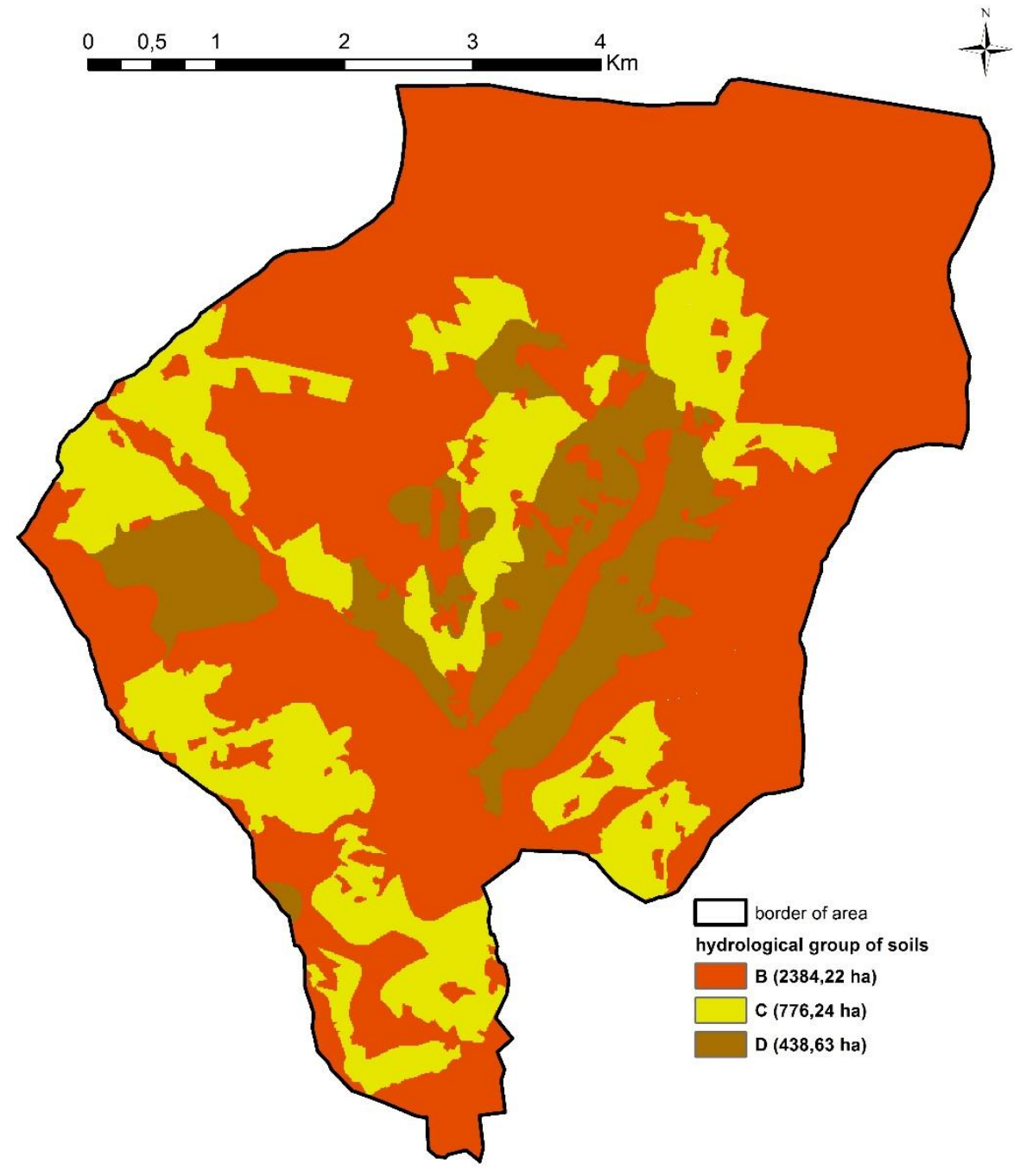

Figure 3. Map of hydrological soil groups(HSG)

\section{Secondary landscape structure}

Secondary landscape structure is a result of human impact on natural landscape. It reflects lifestyle of people, their relationships, values and environmental needs that change over time. In total, 35 elements of the secondary landscape structure were identified on the area of 3611.73 ha (Fig. 4). They were subsequently merged into 18 elements of secondary landscape structure according to the $\mathrm{CN}$ curves methodology (Table 2). Dominant groups of landscape elements are forests $(61.53 \%)$, permanent 
grasslands $(22.7 \%)$, agricultural lands $(10 \%)$, group of built-up areas and communications $(3.13 \%)$, linear vegetations $(1.81 \%)$ and group of streams and wetlands $(0.83 \%)$.

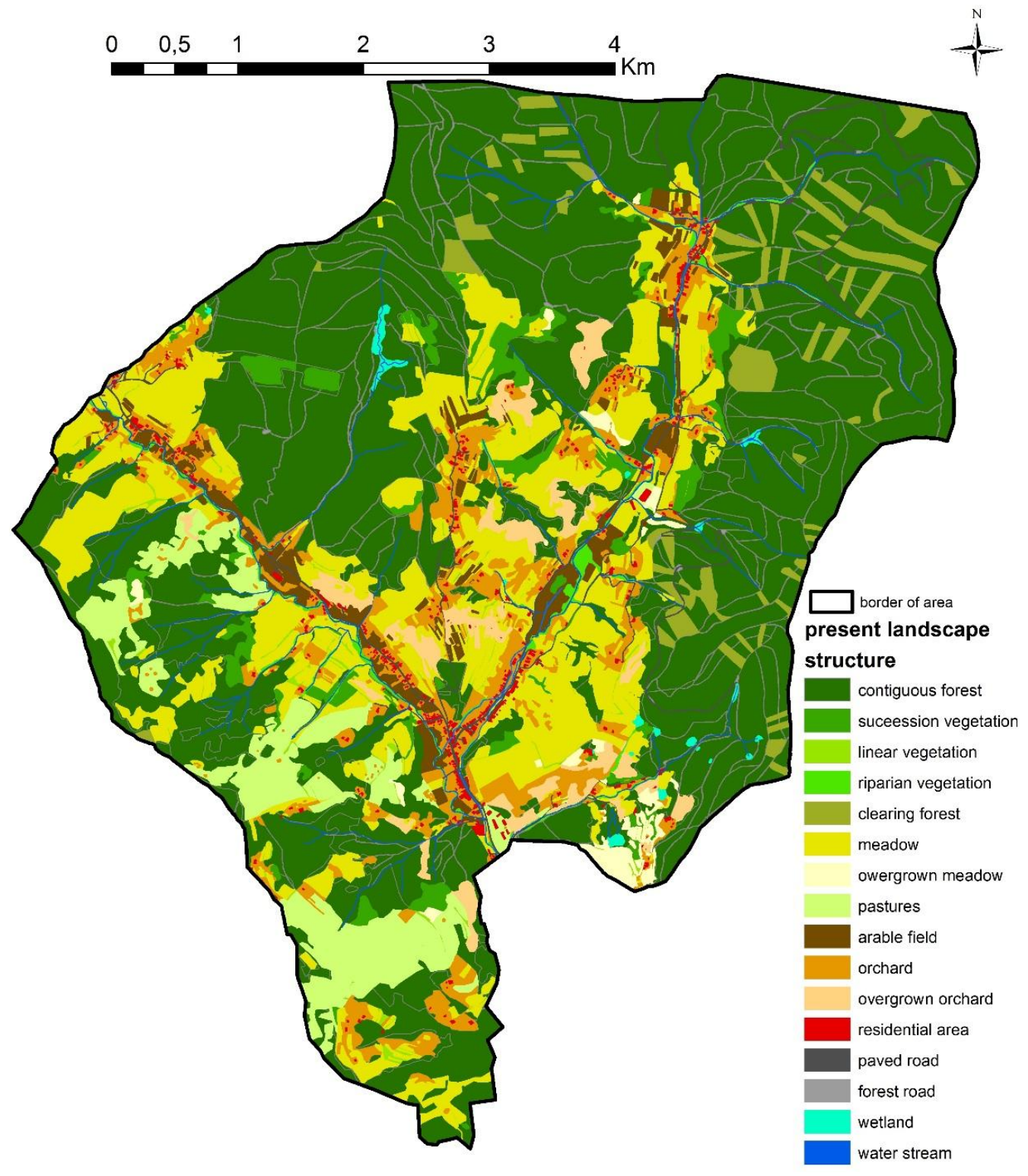

Figure 4. Map of current landscape structure for study area

Continuous forests (1980.79 ha) naturally have the highest hydric potential among all secondary landscape structure elements and provide optimal system for protection and formation of soil. Forest species include many native plants (e.g. European beech, European hornbeam, European ash, wild cherry, European silver) as well as non-native plants (e.g. Norway spruce and European larch). Selective and shelter-wood system is performed for economic logging while windfall logging is preformed in the form of area-wide clear-cuts (effect on the soil is similar to the large-scale clear-cut). From precipitation that falls on the forest, treetops catch approximately $20 \%$, which is called interception loss. Tužinský (2002) reports average interception value for the period 
1981 - 1984 in the range from 20.6 to $26.9 \%$ for area of the Little Carpathians in an adult beech forest (90 years), belonging to the group of forest types Querceto Fagetum in the altitude of $450 \mathrm{~m}$.

Table 2. CN curves values for elements of secondary landscape structure

\begin{tabular}{|l|c|c|c|c|}
\hline $\begin{array}{c}\text { Elements of current landscape } \\
\text { structure }\end{array}$ & $\begin{array}{c}\text { CN curve value } \\
\text { HSG B }\end{array}$ & Area (ha) & Area (\%) & $\begin{array}{c}\text { Hydric } \\
\text { potential }\end{array}$ \\
\hline Contiguous forest & 30 & 1980.79 & 61.53 & very high \\
\hline Riparian vegetation & 36 & 42.43 & 1.17 & very high \\
\hline Linear vegetation & 48 & 23.17 & 0.64 & high \\
\hline Overgrown orchards & 50 & 75.53 & 2.09 & high \\
\hline Orchards & 53 & 199.89 & 5.53 & high \\
\hline Succession vegetation & 56 & 90.77 & 2.51 & high \\
\hline Meadows & 58 & 579.13 & 16.03 & medium \\
\hline Pastures & 61 & 187.67 & 5.19 & medium \\
\hline Overgrown meadows & 62 & 28.95 & 0.80 & medium \\
\hline Small fields & 75 & 85.41 & 2.36 & medium low \\
\hline Forests clearings & 77 & 103.29 & 2.85 & medium low \\
\hline Wetlands & 84 & 8.79 & 0.24 & low \\
\hline Slightly eroded forest roads & 82 & 3.99 & 0.11 & low \\
\hline Medium eroded forest roads & 87 & 43.41 & 1.20 & low \\
\hline Strong eroded forest road & 89 & 20.93 & 0.57 & very low \\
\hline Water streams & 98 & 15.44 & 0.42 & very low \\
\hline Residential area & 98 & 21.79 & 0.60 & very low \\
\hline Paved roads & 98 & 24.42 & 0.67 & very low \\
\hline
\end{tabular}

In the western part of the study area field mapping discovered proportional increase of forest with autochthonous tree species such as silver birch (Betula pendula) and European aspen (Populus tremula). Riparian vegetation covers area of 42.43 hectares. It is formed by linear vegetation and woodlots of common alder (Alnus glutinosa), European ash (Fraxinus excelsior) and white willow (Salix alba). Root system of this vegetation stabilizes shorelines from erosion and slows down the runoff. It is an element with significant hydric and ecological stabilisation value.

Orchards on total of 199.89 hectares are typical feature of the study area. Old and extensively used orchards with grassland represent landscape elements with most appropriate combination of production, hydric and ecostabilizing characteristics within all identified agricultural cultures. Permaculture edible forest that combines production and non-production properties (food, wood) of trees, shrubs and herbs represents even better combination of above mentioned characteristics. There is typical production of apples, plums, peers (Pyrus) and service trees (Sorbus domestica), which are often approximately one hundred and in some cases two or three hundred years old (Fig. 5). The orchards are degrading and are gradually overgrown which is similar also for meadows and pastures. According to mapping growing orchards covered 75.53 hectares. Successional transitions between orchards and forests have been documented.

Meadows and pastures are elements of the agricultural landscape with medium hydric potential. Meadows and pastures cover 579.13 hectares and they are known for their high rate of biodiversity with significant locations of orchid plants. On warmer hillsides, so called "stoklasové" ("hundred ears" - author's free translation) meadows are located. There are large numbers of grasses and flowering herbs such as clustered bellflower 
(Campanula glomerata), European columbine (Aquilegia vulgaris), green-winged orchid (Orchis morio), Hollub's ophrys (Ophrys hollubyana) and many others. Besides meadows, tufa springs on slopes are typical for this area. They are results of landslides, which are common in flysch sequences. These areas, with water-loving vegetation, can be distinguished from the surrounding meadows by cottongrass (Eriophorum) or red flowering thistle (Cirsium rivulare); furthermore we can find here marsch helleborine (Epipactis palustris) and western marsch orchid (Dactylorhiza majalis).

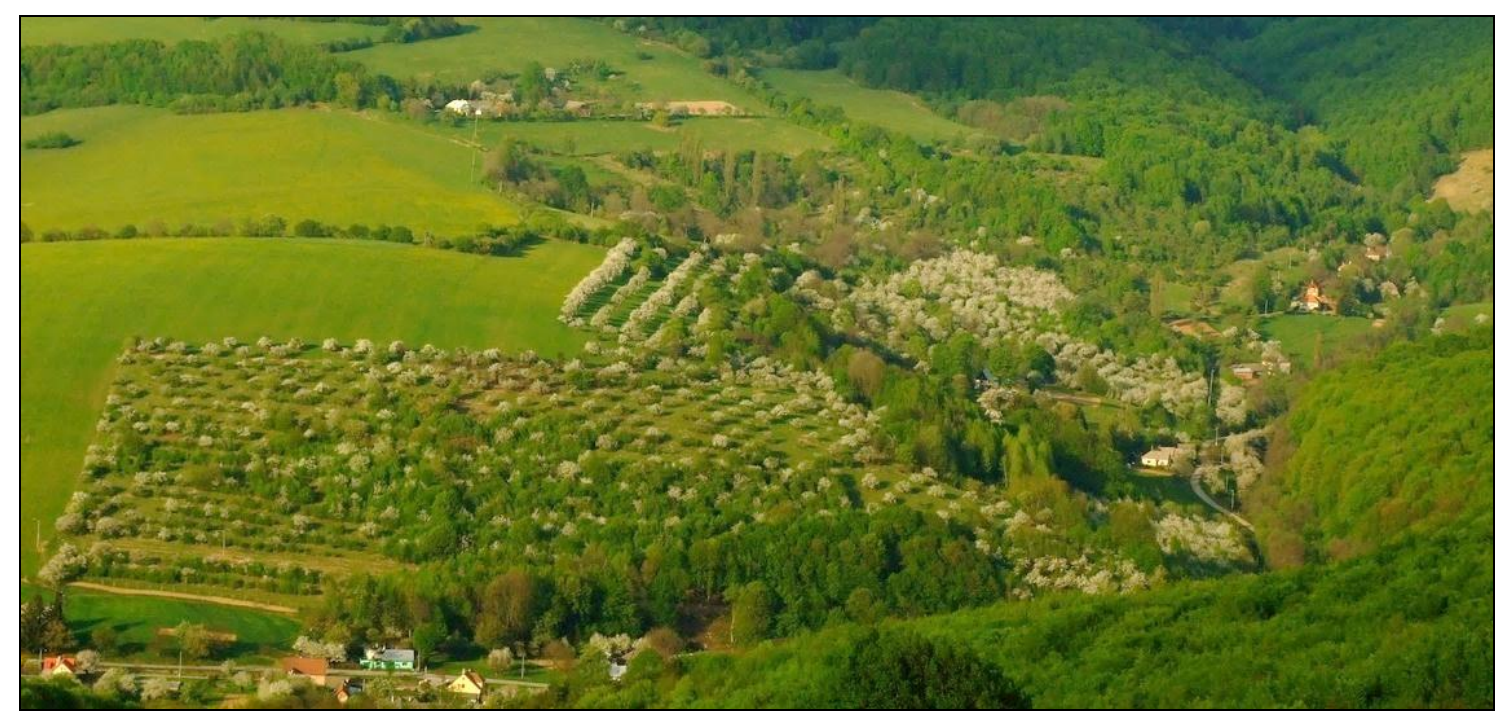

Figure 5. Orchard on the Špaňom, which is managed by organic farm Pangaea since 2013.

Elements with low and very low hydric potential are represented by unpaved forest roads (68.23 hectares), mapped in three categories: heavily eroded (20.93 hectares), medium eroded (43.31 hectares) and slightly eroded (3.19 hectares). With an average width of $4 \mathrm{~m}$, total roads length in the study area is $170 \mathrm{~km}$.

Wetland communities are important ecological components of the landscape. They are represented by forest and meadow springs, representing ecologically significant localities that can be found at 8.79 hectares of the study area. They act as important water collectors since they accumulate during the period of precipitation and gradually release a large amount of water during the period without precipitation (Fig. 6).

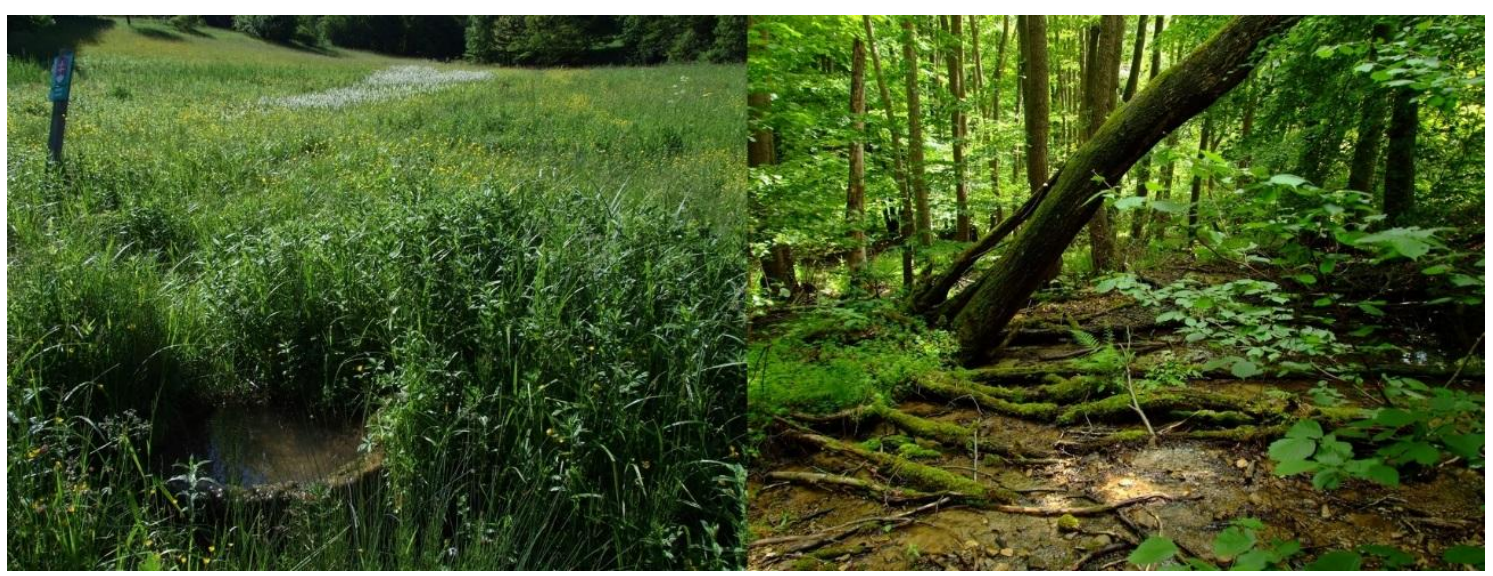

Figure 6. Meadow spring of Blažejová and forests spring in Hubotica 
The whole area is abundant on many animal species, from amphibians, through shellfish and birds to mammals.

Straightened and regulated streams are mainly in urban areas, where the intentions are to divert the water as quickly as possible (Fig. 7). Thus diverted water have the potential to slow down and partly to accumulate in natural streams, with wetlands and floodplain forests situated below settlements, therefore their qualitative and quantitative support can increase the hydric potential of the landscape.



Figure 7. Elements of current landscape structure with very low (1-forest road with high erosion devastation, 2 - regulated stream) and higher hydric potential (3-natural stream)

Agricultural activity in the study area is represented by grazing, mainly of cattle, less sheep, goats and horses. Other areas are covered by various mosaics of hay meadows and orchards. There is no exception to encounter more than a hundred years bearing fruit trees of rare old varieties.

The study area is a part of large protected area of bilateral Protected Landscape Area White Carpathian Mountains, where the second level of environmental protection is present. Ecologically valuable sites have been declared as small protected areas. A large part of the study area is included in the European nature protection sites of NATURA 2000, specifically in the Special Area of Conservation Hollubyho kopanice.

\section{Potential retention}

On the basis of the $\mathrm{CN}$ curve values, values for potential retention of the study area were calculated (Figure 8). According to the $\mathrm{CN}$ curves in the study area, very high and high hydric potential dominates $(58.5 \%)$, mainly in forests; medium and medium-low hydric potential covers $28.3 \%$ of the territory, and low and very low hydric potential covers $13.3 \%$ of the study area. The average value of $\mathrm{CN}$ curve is 78 .

Areas with very low potential retention are landscape elements with impermeable surfaces (settlements, paved roads, waterways) and with elements of naturally very low retention (forest roads, clearings, arable lands) in combination with unfavourable soil properties (soil with very low infiltration capacity and without drainage). According to the calculation, potential retention on soils with very small infiltration capacity is in the forest $169.33 \mathrm{~mm}$, in the orchard $71.44 \mathrm{~mm}$, in the meadow $58.59 \mathrm{~mm}$, and in the arable land $34.64 \mathrm{~mm}$. In the forest road with medium erosion the potential retention is $22.09 \mathrm{~mm}$. 


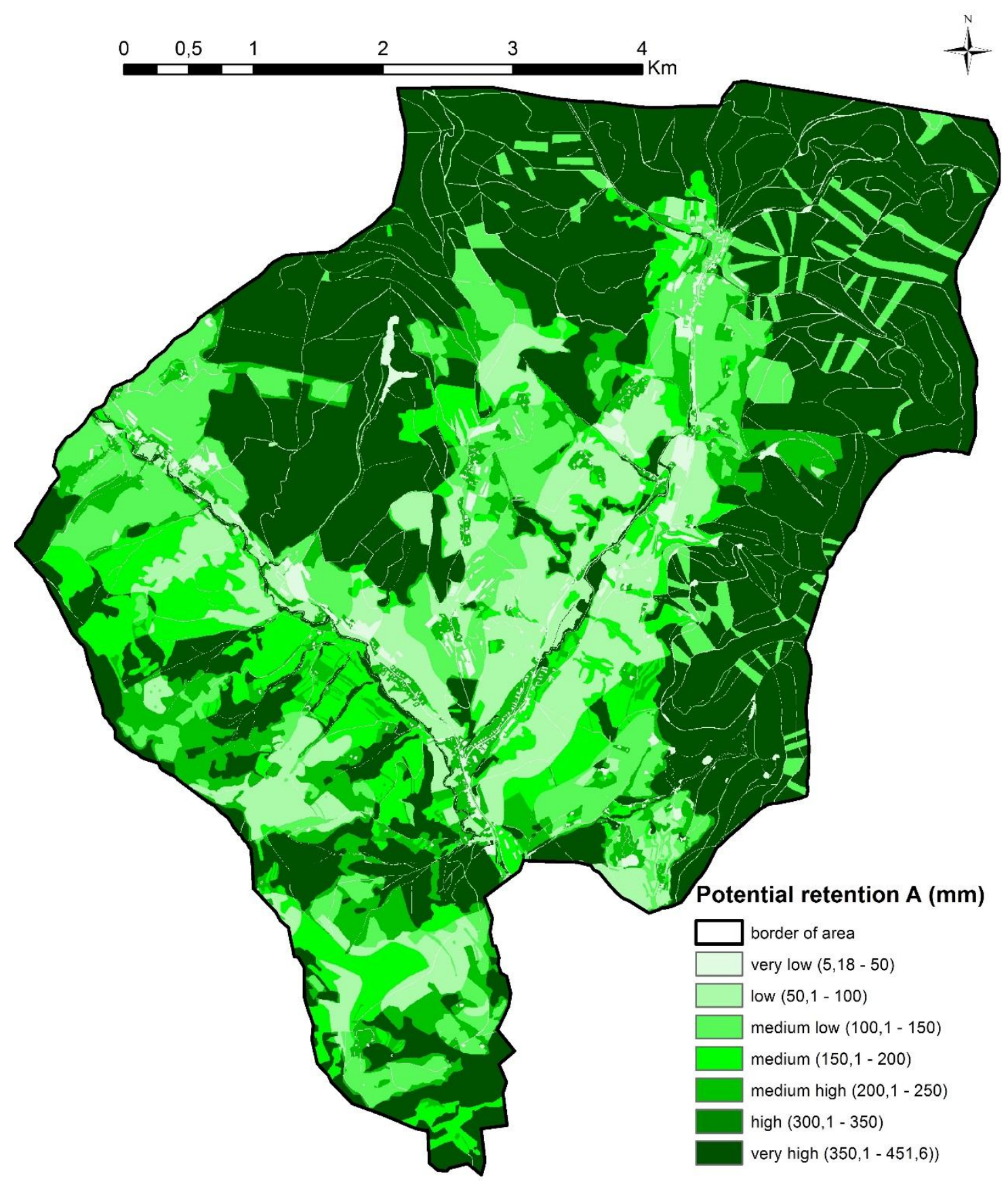

Figure 8. Potential retention of study area

Figure 9 shows the volume of surface runoff for the current landscape structure. The highest volume of surface runoff is naturally concentrated in the stream beds. From the confluence of Bošácka stream and Španie stream, which represent outflow of the study area, the model calculated surface runoff of $787105.8 \mathrm{~m}^{3}$ at proposed $120.2 \mathrm{~mm}$ precipitation. Significant increase of surface runoff is recorded in the clearings on steep slopes. The increased outflow was also recorded in localities with hydrologic soil group D (soils with very low infiltration capacity and without drainage) and hydrologic soil group C (soils with low infiltration ability with low drainage). These soils in the lower parts of slopes are used as arable land, pastures and meadows. 


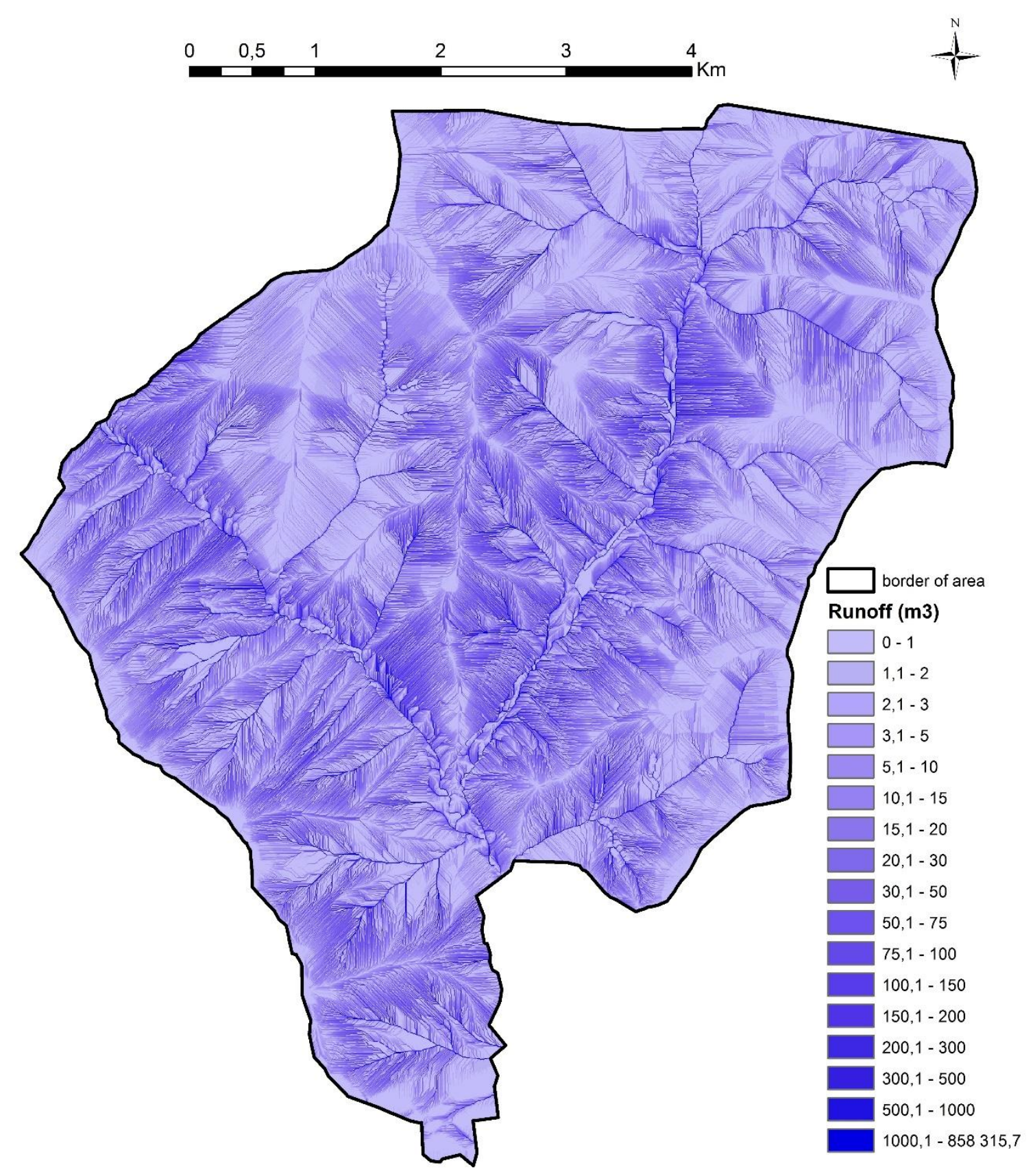

Figure 9. Volume map of surface runoff in study area for current landscape structure

\section{Proposition of optimized landscape management}

Based on both analyses and synthesis of here presented results, optimized landscape management in the study area should include following propositions: Economic activities should be excluded on localities with forest springs mapped during field works. Localities with non-forest springs should be excluded from grazing. It is recommended to exclude forestry activities also in a $10 \mathrm{~m}$ buffer zone around water courses and to create protecting buffers around them. To protect natural processes of the major hydrological basin with ecologically stable old beech forest, a natural reserve with area of 240 ha should be declared. 
Considering forest road network, at least $50 \%$ of present roads should be destroyed by disrupting compact surface with excavator and left to successional processes. The selection should be undertaken by professional forest managers. Remaining roads should be maintained in terms of technical standards (STN 73 6108) and should be accompanied by drainage channels which enable water to flow into surrounding vegetation. Tow of logged wood should be carried out in winter month when the ground is frozen and covered with snow. On steep slopes use of traditional forms of forest work with workhorses is recommended.

In terms of hydric functions, wetland Močarina in Predpolomská valley on Predpolomský stream is significant due to its location and size. As part of the intensification of agriculture the system of drainage channels was built and ash-alder alluvial forests were changed to arable land. In terms of increasing landscape retention and accumulation function, this wetland should be revitalized on the area of 22 hectares (Fig. 10). The recommendations are to abolish drainage channels system by burying pipes and leaving smaller ponds, and changing agricultural land use to flood protection use by restoring functional forest ecosystem instead of arable land and meadows.

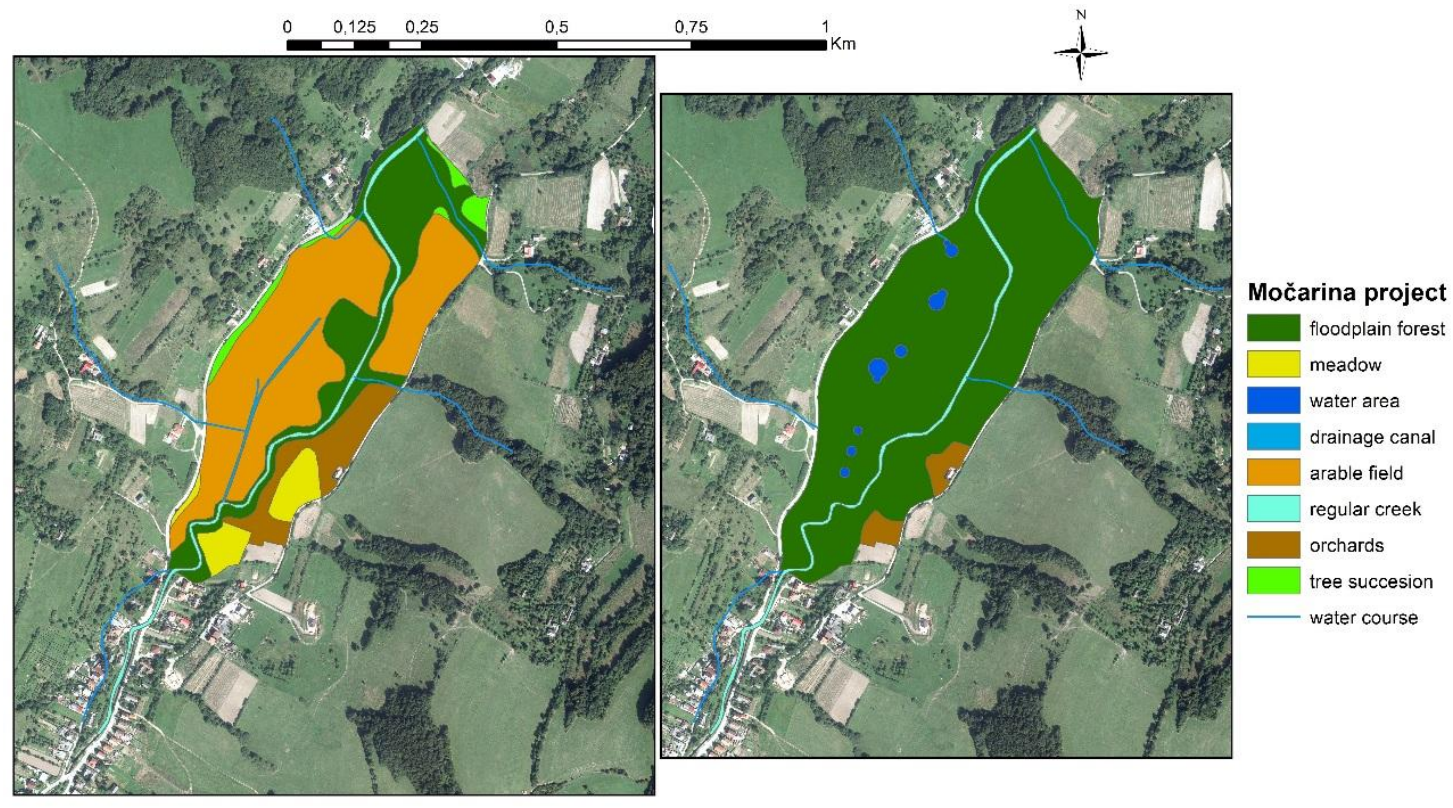

Figure 10. Proposal for Močarina wetland restoration, changing agricultural land use to flood protection, by supporting viable ecosystem of floodplain forest

The study area has quite well-preserved functional landscape structures on agricultural land, created by generations, which include hedgerows of fruit trees and shrubs planted along the contour lines. They divide meadows and pastures on the long slopes, creating a barrier for runoff and wind, and thus protecting agricultural land from water and wind erosion. Also existing network of riparian vegetation is in relatively good condition. To increase hydric functions of the landscape the existing structure of hedges as well as riparian vegetation should be supplemented with further landscape elements (for instance in the form of shrubs and fruit trees in a 6-10 wide strip along contour lines) which will divide long slopes in some localities where these slopes occur without existing landscape structures. Another measure for increasing hydrological 
conditions of arable land consists of planting a 2-3 m wide strip of riparian vegetation in the form of fast-growing energy crops (willow, hazel), which will be coppiced and will bring the economic effect, either in the form of biomass for energy production, or as rods used in basketry.

In localities on soils with very low infiltration capacity, the recommendations are to adjust their use in order to improve quality of soil by converting them into an edible forest. The concept of edible forest respects the climax stage of a locality and may lead to optimal spatial and age structure. Species suitable for this type of forest are sweet chestnut (Castanea sativa), common walnut (Juglans regia), common hazel (Corylus avellana), edible species of rowan (Sorbus) and many others. Successful example of functionality of this concept in the Central European conditions is sweet chestnut forest in the mountains of Tríbeč, where main trees form forest vegetation with optimal age and spatial structure.

From proposed measures, ecologically sustainable forest management has the most significant effect as it concerns a large part of the study area. All proposed measures have ecosystem character, thus achieving optimized landscape structure. The results of hydrological modelling show volume values of surface runoff in study basin (for the proposed $120 \mathrm{~mm}$ precipitation), which have been established for potential landscape structure representing the highest hydric potential $\left(159318 \mathrm{~m}^{3}\right)$, current landscape structure $\left(858315 \mathrm{~m}^{3}\right)$ and the proposed landscape structure $\left(733856 \mathrm{~m}^{3}\right)$. The fundamental difference between current landscape structure and proposed landscape structure is reflected in the increasing size of settlement with very low volume of surface runoff by $13.1 \%$ (473 ha). By applying proposed measures, according to calculations of modelling software, the volume of surface runoff in study area would be reduced by $124459 \mathrm{~m}^{3}$ in the proposed $120 \mathrm{~mm}$ precipitation (Fig. 11).

\section{Discussion and conclusions}

Smiraglia et al. (2015) underline the importance of integrated methodologies based on mixed quantitative and narrative approaches to achieve a thorough comprehension of landscape changes. Application of LANDEP methodology provides among others possibilities for landscape-ecological optimization of hydric potential. Using the universal legend of landscape elements (Petrovič et al., 2009) and method of CN curves to calculate the volume of runoff (Gajdošík et al., 2005) landscape ecological optimization was implemented in the upper part Bošáčka basin in the central part of the White Carpathians. Typical feature of the study area is represented by dispersed settlements, which form mosaic of forests, orchards, meadows, pastures and wetlands. Košt’ál (2010) indicates that colourful meadows with rich diversity, which is typical for the Biele Karpaty Mts., suffered mainly after World War II, during the socialist collectivization. Elements with low hydric potential are typical for disturbed soil cover with sparse or even no vegetation.

Conversion of land to agriculture, mining, industrial, or residential uses significantly alters the hydrologic characteristics of the land surface and modifies pathways and rates of water flow (Bhaduri et al., 2000). Other negative factors for hydric potential include massive logging. According to Kantor and Šach (2002) erosion processes in clearings are not only the result of felled trees, but they are also an expression of poorly organized deployment and movement of heavy machinery and another human activities. An extreme negative impact of such activities on soil quality and thus hydric potential of 
the landscape can be seen especially on flysch bedrock, which was confirmed by various authors (Simon and Sucharda, 2004; Baláž et al., 2008). A suitable alternative is selective logging, taking into account the soil protection.

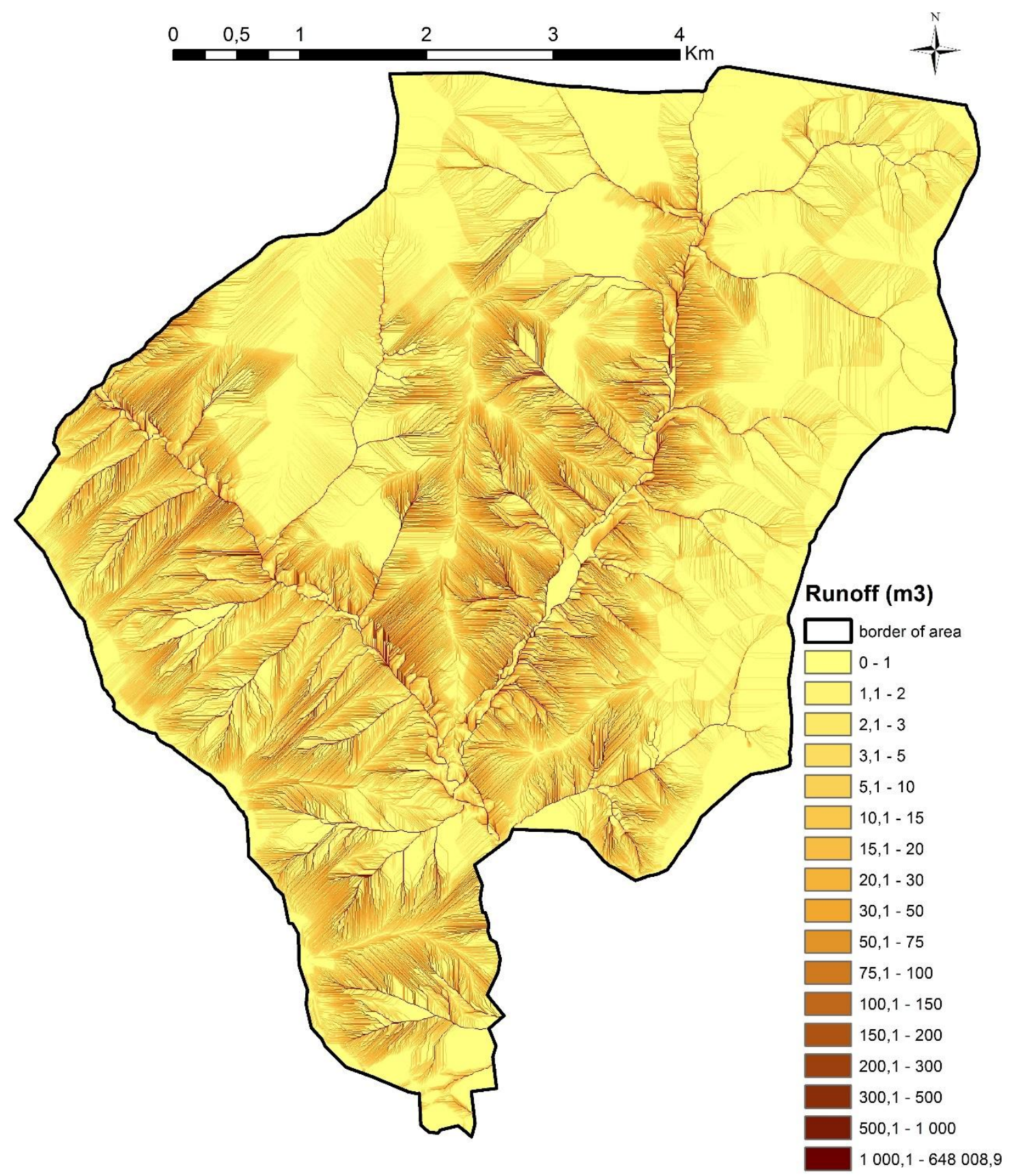

Figure 11. Volume map of surface runoff for proposed (optimized) landscape structure

Forest stands are an important factor in terms of their impact on the quantity and quality of water resources (Abildtrup, Garcia and Stenger, 2013; Erol and Randhir, 2013; Fiquepron, Garcia and Stenger, 2013; Lima et al., 2016). A significant problem during torrential rain in forested land is a dense network of logging roads. Paved surfaces in forest ecosystems concentrate surface runoff, increasing drainage density of 
basin and are source of $30-80 \%$ sediment transported in the rivers (Hagans et al., 1986). Surface runoff on logging roads can reach up to 1300 time the surface runoff in the adult forest which means that almost all water that falls on logging roads flows away. $95 \%$ of this water gets in streams (Midriak, 2004). Up to $99 \%$ of soil loss in forest comes from unpaved roads and only small amount from the surface of undisturbed land in forests. Compacted linear surfaces are often directly constructed or eroded as deep cuts into the slope terrain, resulting into slope drainage and transformation of subsurface to surface runoff which consequently leads to speeding up outflow from the basin in the form of flash floods after torrential rains. Therefore, revitalization of forests roads and supporting the non-forest vegetation is necessary. Important are mainly riparian vegetation restoration near communication. Riparian ecosystems play a vital role in providing ecosystem services that include habitat support and protection of water quality (Randhir and Erol, 2013; Munteanu et al., 2014; Chen et al., 2016; Schroeder-Georgi et al., 2016).

Final step in LANDEP is proposing environmentally optimal localization of socioeconomic activities in the landscape which leads towards harmonization of landscape ecological characteristics with its current and proposed use (Ružička, 2000). In the studied basin the volume of surface runoff as a representative of hydric function of the landscape is the main object of decision-making process in this final step. Proposed objectives are the elements of the current landscape structure, reflecting the society activities. The aim is therefore to harmonize land use with its hydric potential, leading to increase of the retention and accumulation functions which represent ecological quality of the landscape. Based on the analysis of localities with large volume of surface runoff for current landscape structure, optimized landscape structure was proposed. The main proposed measure is ecological forest management since forests represent optimal ecosystems of retention and accumulation of rainwater in the study area.

Other recommendations for landscape optimization in order to achieve increase in hydric functions of the study area include establishment of a protected area, restoration of a wetland, restoration of forest road network or planting edible forests in localities with soils with very little infiltration capacity and without drainage. Proposed optimization measures were implemented in the model of proposed landscape structure. This resulted in the change of land use layers entering calculation of $\mathrm{CN}$ curves and consequently in the change of the $\mathrm{CB}$ curves.

Analysis and hydric evaluation of the study area shows that foothills region has a relatively high hydric potential. The proposed measures are linked to existing landscape structure, where they increase the quality of existing hydric elements. They have character of non-technical solutions with maximum exploitation of the potential of ecosystem services, therefore they are economically undemanding. With their application, according to software modelling calculations, volume of surface runoff in study area can be significantly reduced. This represents an effective instrument of flood protection with ecosystem approach. It is essential, however, to implement them into integrated river basin management by all entities using the landscape.

Landscapes and watersheds are complex cultural biogeoclimatic systems that are not easily bounded, measured or understood by a single body of expertise. This makes it very challenging to locate and synthesize the best available science to identify what decision-makers need to know about landscape and watershed impacts of hydraulic fracturing. 'Landscape' is not a physical object as much as it is a spatial context for multiple natural processes and human activities (Quinn et al., 2015). 
In our paper we used methods as LANDEP and integrated landscape management, by means of which we tried to show the possibility of improving the water management. It is possible in areas where is enough water but its use can be rationalized by changes in land use. On the basis of our results, the synthesis of both methods confirms its suitability for such proposals to deal with the problems in landscape.

Acknowledgements. The contribution was prepared within the grant projects of Slovak Scientific Grant Agency VEGA no 1/0496/16 and VEGA no 1/0673/16.

\section{REFERENCES}

[1] Abildtrup, J. Garcia, S., Stenger, A. (2013): The effect of forest land use on the cost of drinking water supply: A spatial econometric analysis. - Ecological Economics 92: 126136.

[2] Antal, J., Igaz, D. (2006): Aplikovaná agrohydrológia (in Slovak). - SPU. Nitra

[3] Bastian, O. (2001): Landscape Ecology - towards a unified discipline? - Landscape Ecology 16: 757-766.

[4] Baláž, E., Kotecký, V., Machalová, L., Poštulka, Z. (2008): Vlyv holosečného hosporaření na půdu, vodu a biodiverzitu (in Czech). - Hnutí Duha, Brno.

[5] Bhaduri, B., Harbor, J., Bernie, E., Grove, M. (2000): Assessing Watershed-Scale, LongTerm Hydrologic Impacts of Land-Use Change Using a GIS-NPS Model. Environmental Management 26(6): 643-658.

[6] VÚPOP (2013): Rated soil ecological units -maps (BPEJ) - VÚPOP, Bratislava.

[7] Directive 2000/60/EC of the European Parliament and of the Council establishing a framework for the Community action in the field of water policy.

[8] Drégelyi-Kiss, Á., Drégelyi-Kiss, G., Hufnagel, L. (2008): Ecosystems as climate controllers - biotic feedbacks (a review). - Applied Ecology and Environmental Research 6(2): 111-135.

[9] Estrada-Carmona, N., Hart, A. K., DeClerck, F. A. J., Harvey, C. A., Milder, J. C. (2014): Integrated landscape management for agriculture, rural livelihoods, and ecosystem conservation: An assessment of experience from Latin America and the Caribbean. Landscape and Urban Planning 129:1-11.

[10] Erol, A., Randhir, T. O. (2013): Watershed ecosystem modeling of land-use impacts on water quality. - Ecological Modelling 270: 54-63.

[11] Forman, R.T., Gordon, M. (1993): Krajinná ekologie (in Czech). - Academia, Praha.

[12] Fiquepron, J., Garcia, S., Stenger, A. (2013): Land use impact on water quality: Valuing forest services in terms of the water supply sector. - Journal of Environmental Management 126: 113-121.

[13] Gajdošík, P., Šulík, V., Trizna, M., (2005): Vplyv zmeny priestorovej štruktúry krajiny na odtok vody z povodia (in Slovak). - Geografické spektrum 4 Bratislava, Geo-grafika.

[14] GWP (Global Water Partnership) (2000): Integrated water resources management. - TAC Background Papers, No. 4.

[15] Hagans, D. K., Weaver, W.E., Madej, M.A. (1986): Long term on-site and off-site effects of logging and erosion in the redwood creek basin, Northern California. - Technical Bulletin, New York: 38-66.

[16] Haines-Young, R. and Potschin, M. (2008): England's terrestrial ecosystem services and the rationale for an ecosystem approach. - Full technical report, CEM, School fo Geography, University of Nottingham.

[17] Hrnčiarová, T. (2003): Krajinnoekologické plánovanie - podklad pre integrovaný manažment krajiny a priestrové plánovacie procesy (in Slovak). - In: Geografické aspekty sředoevropského prostoru. Brno. PdF MU: 265-269. 
[18] Hrnčiarová, T., et.al. (1997): Ekologická únosnost' krajiny: metodika a aplikácie na 3 benefičné územia, I.-IV. Čast'. (in Slovak). - Ekologický projekt MŽP SR Bratislava, ÚKE SAV Bratislava .

[19] Izakovičová, Z. (2000): Example of the stress factors in the landscape. - Ekológia (Bratislava) 24 (3): 277-291.

[20] Janeček, M. (2002): Ochrana zemědělské půdy před erozí (in Czech). - ISV, Praha.

[21] Kantor, P., Šach, F. (2002): Možnosti lesu při tlumení povodní (in Czech). - Lesnícky výskum 11: 493-495.

[22] Koštál, J. (2010): Povestné bielokarpatské lúky (in Slovak). - Krásy Slovenska 87( 5-6): 30-31.

[23] Kozma, K., Puskás, J., Drégelyi-Kiss, Á. (2014): The changes in precipitation during 124 years and its influences on the physical conditions of Hernád river. - Applied Ecology and Environmental Research 12(2): 523-536.

[24] Kozová, M., Pauditšová, E. (2001): Evaluation of the landscape structure and its changes for Local Agenda 21. - Ekológia (Bratislava) 20(3): 36-44.

[25] Kravarčík, P., et al. (2000): Nová Bošáca roky 1950-2000 (in Slovak). - Obecný úrad Nová Bošáca: 198 p.

[26] Lepeška, T. (2005): Základné princípy integrovaného manažmentu povodí (in Slovak). Vodohospodársky spravodajca 7-8, Bratislava: 6-8.

[27] Lepeška, T. (2013): Hydric potential of selected river basins in Slovakia. - Ecohydrology \& Hydrobiology 13:201-209.

[28] Lieskovský, J., Bezák, P., Izakovičová, Z. (2010): Protection of represenatative landscape ecosystem of Slovakia. new landscape ecological aproach. 10th International Multidisciplinary Scientific GeoConference SGEM 2010, vol. II: 717-723.

[29] Lima, G. T. N. P. D., Hackbart, V. C. D. S., Bertolo, L. S., Santos, R. F. D. (2016): Identifying driving forces of landscape changes: Historical relationships and the availability of ecosystem services in the Atlantic forest. - Ecosystem Services 22( 1): 1117.

[30] Midriak, R. (2004): Od erózneho ohrozenia po spustnuté pôdy Slovenska (in Slovak). Tretie pôdoznalecké dni v SR. VÚPOP Bratislava: 193-200.

[31] Miklós, L. (1996): The concept of the territorial system of ecological stability in Slovakia. - In: Jongman, R.H.G. (Ed.): Ecological and landscape consequences of land use change in Europe. ECNC publication series on Man and Nature 2, Tilburg: 385406.

[32] Miklos, L., Špinerová, A. (2011): Krajinno-ekologické plánovanie LANDEP (in Slovak). VKÚ, Harmanec, 158 p.

[33] Muchová, Z., Leitmanová, M., Petrovič, F. (2016): Possibilities of optimal land use as a consequence of lessons learned from land consolidation projects (Slovakia). Ecological Engineering 90( 5): 294-306.

[34] Munteanu, C. Kuemmerle, T., et al. (2014): Forest and agricultural land change in the Carpathian region-A meta-analysis of long-term patterns and drivers of change. - Land Use Policy 38: 685-697.

[35] Naveh Z., Liebermann A. S. (1990): Landscape Ecology: Theory and Application. - New York: Springer-Verlag

[36] Pavličková, K., Spišiak, P., Kusendová, D. (2004): Ecological stability of agri-structures in submountain region. - Ekológia (Bratislava) 23(1): 264-273.

[37] Petrovič, F., Bugár, G., Hreško, J. (2009): Zoznam krajinných prvkov mapovatel’ných na území Slovenska (in Slovak). - GEO Information. Nitra: UKF 5: 112 - 124.

[38] Randhir, T. O., Erol, A. (2013): Water quality change and habitat potential in riparian ecosystems. - Ecohydrology \& Hydrobiology 13: 192-200.

[39] Rozsívalová, P. (2007): Implementace Katalogu netechnických protipovodňových opatření do prostředí ESRI produktu (in Czech). - http://gislib.upol.cz/app/katalog/ 
[40] Ružička, M. (2000): Krajinnoekologické plánovanie - LANDEP I. (Systémový prístup v krajinnej ekológii) (in Slovak). 1 vyd. Nitra : Biosféra

[41] Ružička, M., Miklós, L. (1982): Landscape-ecological Planning (LANDEP) in the Process of Territorial Planning. - Ekológia (ČSSR) 1(3): 297-312.

[42] Quinn, M. et al. (2015): Landscape Impacts of Hydraulic Fracturing Development and Operations on Surface Water and Watersheds. Canadian Water Network. - Institute for Environmental Sustainability, Mount Royal University, Calgary, AB., 375 p.

[43] Schroeder-Georgi, T., Wirth, C., Nadrowski, K., Meyer, S.T., Mommer, L., Weigelt, A. (2016): From pots to plots: hierarchical trait-based prediction of plant performance in a mesic grassland. - Journal of Ecology 104(1): 206-218.

[44] Simon, O., Sucharda, M. (2004): Vplyv hospodaření v krajine na průběh a účinek povodní in (in Czech), Hnutí Duha, Brno

[45] Smiraglia, D., Ceccarelli, T., Bajocco, S., Perini, L., Salvati, L. (2015): Unraveling Landscape Complexity: Land Use/Land Cover Changes and Landscape Pattern Dynamics (1954-2008) in Contrasting Peri-Urban and Agro-Forest Regions of Northern Italy. Environmental Management 56(4): 916-932.

[46] STN 736108 Forest Transportation Network (in Slovak). - Zvolen.

[47] Tužinský, L. (2002): Soil moisture in mountain spruce stand. - Journal of Forest Science 48(1): 27-37.

[48] USDA (1986): Urban Hydrology for Smoll Watersheds. - Second Edition, Washington,

[49] Van Beek J. L. (1981): Planing for integrated mamagement of the Atchafalaya river basin: natural system viability and policy constraints. - In: North, R. M., Dworksy, L. B., Alee D. J. (eds.) Unified river basin management. American water research association, Minnesota, USA: 328-337.

[50] Walmsley J. J. (2002): Framework for Measuring Sustainable Development in Catchment Systems. - Environmental Management 29(2): 195 - 206.

[51] Ward, D, A., Trimble, W. S. (2004): Environmental Hydrology. - Lewis Publisher. 